\title{
Stability conditions of the Vistula Valley attained by a multivariate approach - a case study from the Warsaw Southern Ring Road
}

\author{
Łukasz Kaczmarek*, Paweł Dobak \\ University of Warsaw, Faculty of Geology, Al. Żwirki i Wigury 93, 02-089 Warszawa, Poland \\ * corresponding author, e-mail: lukasz.kaczmarek@uw.edu.pl
}

\begin{abstract}
Localised landslide activity has been observed in the area of the plateau slope analysed, in the vicinity of the planned Warsaw Southern Ring Road. Using calculation models quantitative and qualitative evaluations of the impact of natural and anthropogenic load factors on slope stability (and hence, safety) are made. The present paper defines six stages of slope stability analysis, leading to an indication of optimum slope design in relation to the development planned. The proposed procedure produces a ranking of factors that affect slope stability. In the engineering geological conditions under consideration, the greatest factors impacting degradation and failure of slope stability are changes in soil strength due to local, periodic yielding and the presence of dynamic loads generated by intensification of road traffic. Calculation models were used to assess the impact of destabilisation factors and to obtain mutual equivalence with 3D-visualisation relations. Based on this methodology, various scenarios dedicated to specific engineering geological conditions can be developed and rapid stability evaluations of changing slope loads can be performed.
\end{abstract}

Keywords: slope stability, engineering geology modelling, shear strength parameters, glacial tills, Central Poland

\section{Introduction}

Analysis of Vistula Valley slope stability in the vicinity of the Warsaw ring road is a classic example of vital interaction between the geological environment and engineering practice, where swift evaluation of slope stability in relation to urban development is a fundamental issue. When mass movement initiates there is no time or possibility to begin new research. Local landslide movements have appeared recently in southern districts of Warsaw. The planned Warsaw Southern Ring Road intersects the Vistula Slope (so-called the Warsaw Slope). Construction of the Warsaw ring road is needed for the city's traffic network, in spite of geodynamic activities observed in this area.

A synthesis of Vistula Slope stability in Warsaw was provided by Wysokiński (1999), in which key data on landslide activity can be found. Spatial development in the south Warsaw area led to these geodynamic movements that were noted in sections analysed of the southern slope on the border between the Ursynów and Wilanów districts. Geomorphological and geophysical analysis of Vistula Slope stability conditions at the chosen site were initially conducted by Kaczmarek (2014). An example of numerical stability assessment and foundation conditions near the church of the Blessed Edmund Bojanowski (12 Kokosowa Street), situated on the edge of the Vistula Slope in the vicinity of the Warsaw ring road, was provided by Koda \& Rabarijoely (2013). Furthermore, due to property development interests, numerous commercial tests and engineering geological reports have appeared recently. Among the more important ones is the report prepared by Grzelewski et al. (2009) that pre- 


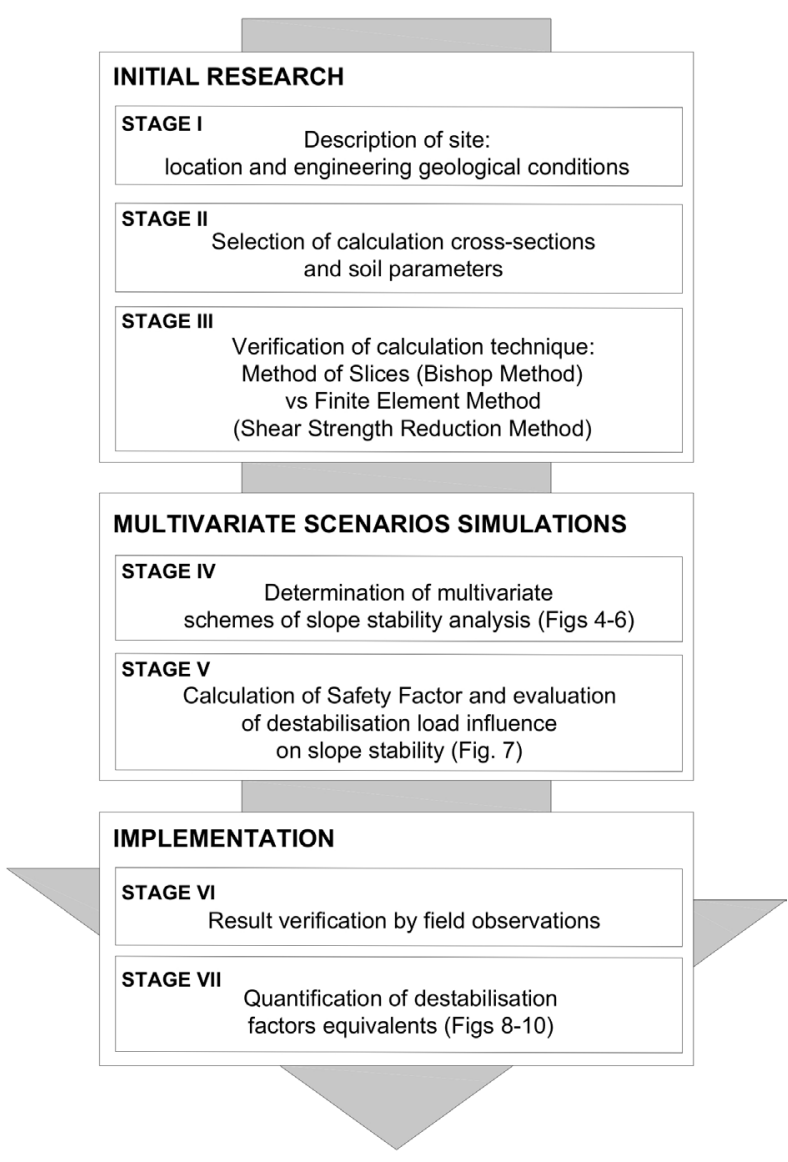

Fig. 1. Workflow of slope stability multivariate analysis

sents results of field and laboratory tests of the area analysed.

In the present paper, landslide activities related to geology, destabilisation loads and case records are extracted for the purpose of the proposed numerical multivariate slope stability methodology. To investigate the suitability of the procedures presented, a case study of the Vistula Valley slope near Warsaw Southern Ring Road was used. Figure 1 presents slope stability evaluation procedures.

\section{Site description}

\subsection{Location}

While there are fewer river valley landslides than landslides in mountainous areas, population density may make them dramatic in consequence. The rolling landscape makes the Vistula Slope one of the most attractive places in Warsaw for housing. Increasing population pressure requires more road links. The Vistula Slope is a natural border between the Warsaw Plain and Middle Vistula Valley, and the study area is located along the boundary between the Ursynów and Wilanów districts (Fig. 2).

Two computational cross-sections illustrate engineering geological conditions of the area analysed (Fig. 3). The first is located on the axis of the planned Warsaw South Ring Road, currently Płaskowickiej Street (Fig. 2). The slope is $12 \mathrm{~m}$ high and has a $41^{\circ} \mathrm{dip}$. The top edge of the slope is loaded by local traffic (dynamic loads) but the Warsaw South Ring Road will generate mega higher traffic intensity in future. The second cross-section is situated approximately $275 \mathrm{~m}$ north of the first one (Fig. 2), near Kiedacza Street. The Vistula Slope is $15 \mathrm{~m}$ high and has a $34^{\circ}$ dip. Presently, the slope is loaded by its own weight, without any anthropogenic influence. However, there are plans to build blocks of flats near the top edge of the slope. Occasionally, at the foot of the slope there will be dynamic loads generated by vehicles.

As a first step field observations with archive records of potential computational cross-sections were made. In 2010 a catastrophic landslide took place in the research area (Fig. 2), with deep slide surface. As a result of this event two buildings were destroyed. The main factor inducing this landslide was the static load of the top edge of the slope and long downpour, which caused the reduction of soil strength. Furthermore, three years of field observations revealed information about local near-surface soil creep.

\subsection{Engineering geological conditions}

The crown of the Vistula Slope is composed of two till layers and fluvioglacial sandy layers of Pleistocene age. The tills have different consolidation characteristics. The Odranian complex has a better properties than the younger Wartanian tills. These deposits are underlain by Neogene clays (Mio-Pliocene complex) with a northeast dip, and therefore they have no influence on stability conditions. A typical soil profile in the area nalysed is presented in Fig. 3.

Shear strength parameters of soils based on various sources (Pinińska, 1985; PN/B-03020, 1991; Frankowski et al., 2000; Grzelewski et al., 2009; Kaczyński, 2011) were analysed. The results of these tests show a wide range of cohesion (c) and internal friction angle $(\varphi)$ values, dependent of structure and moisture soil changes. Primary genetic conditions are continuously modified, due to weathering processes and mass movement activity, hence strength parameters are decreasing. This change is evident, especially in superfacial zones of the slope. The graphs of cohesion vs moisture (Fig. 4A) and 

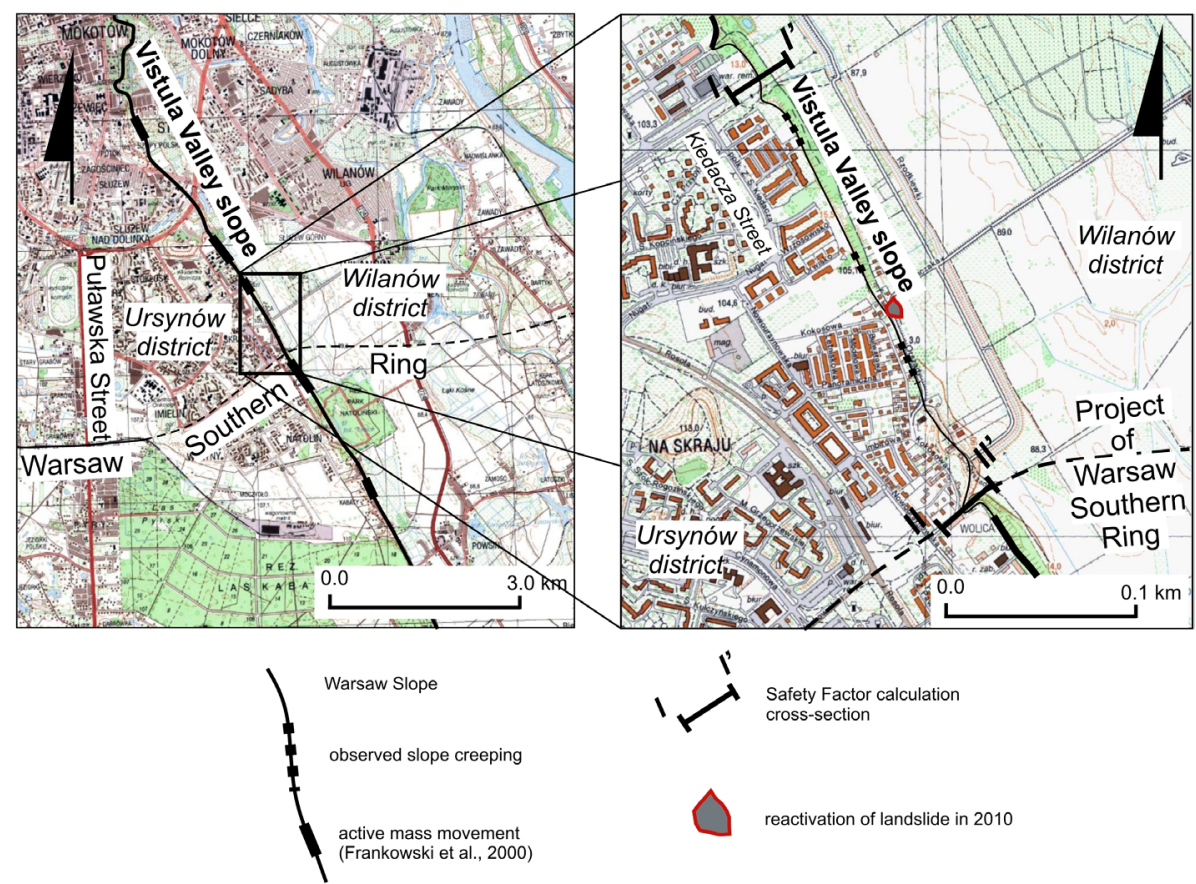

Fig. 2. Location of study area and computational cross-sections of the southern part of the Vistula Slope in Warsaw

A

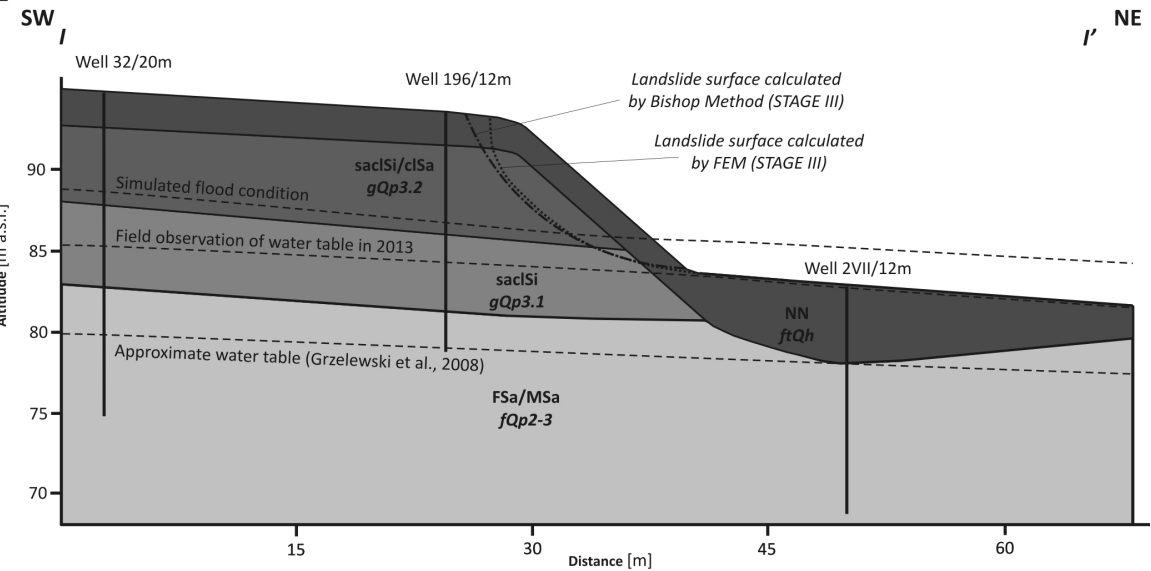

B

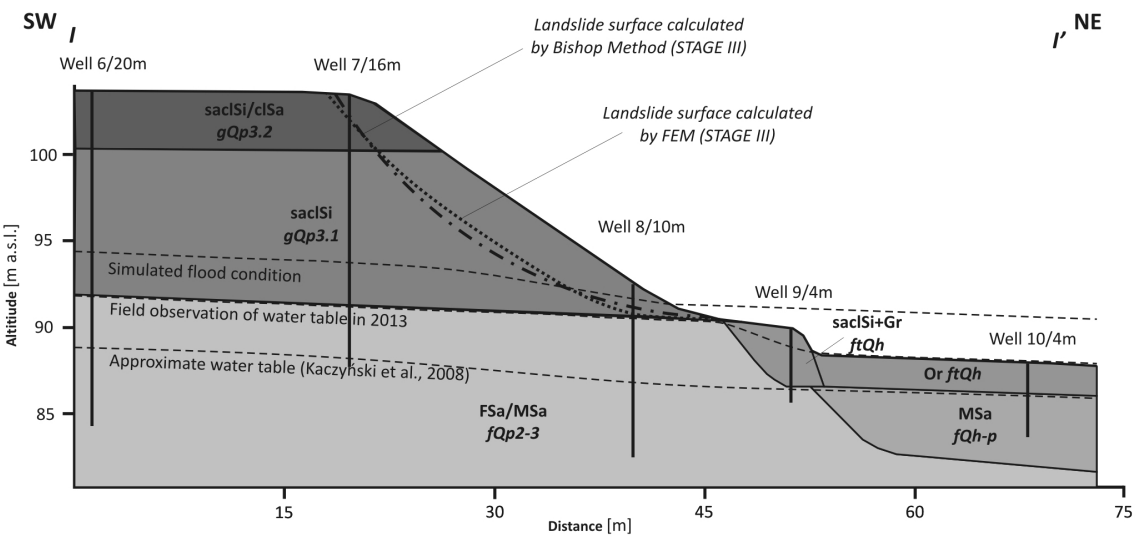

Fig. 3. Computational cross-sections along the axis of the Warsaw South Ring Road Project (A) and near Kiedacza Street (B) 

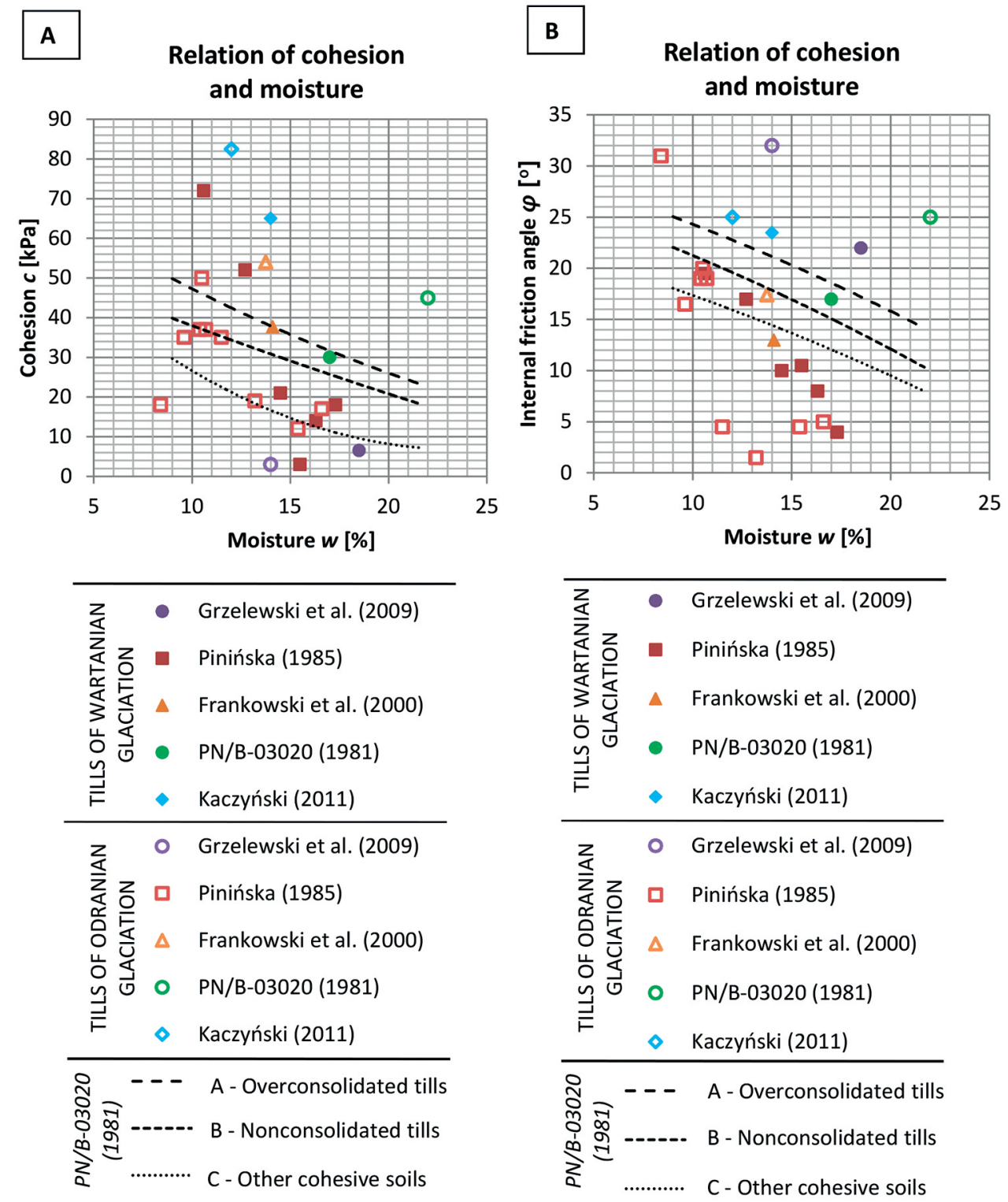

Fig. 4. Cohesion and internal friction angle in relation to soil moisture according to local, regional and most typical soil correlations in reports published

internal friction angle vs moisture (Fig. 4B) confirm these conclusions. Figure 4 also presents relations regarding soils with typical characteristics presented in Polish Standards (PN). The changes observed are connected with lithology (tills and hollow soils) under different overconsolidation states. In terms of typical relations three groups of test results may be distinguished. The first group has values higher than typical characteristics for overconsolidated stiff tills (line A). The next group has similar characteristics to line B related to different tills and hollow soils. Soils which have parameter values lower than typical, normally consolidated hollow soils (group C) probably may present the state of soil responsible for mass movements.
The weak soil layers and privileged slip surface lead to landslide most frequently. In stiffer, homogeneous layers the thickness of the soil complex is of a greater importance for slope stability, especially when mass movement is caused by overloading. Regarding variability of internal friction angle values and cohesion parameters of these tills, four selected parameter sets (Table 1) were used for the next stages of slope stability calculation simulations.

The first set of parameters were based on an engineering geological report prepared for the Warsaw South Ring Road (Grzelewski et al., 2009), the second on triaxial tests performed by the Engineering Geology Laboratory of Warsaw University (Pinińska, 1985; Dobak \& Pinińska, 1987), the third on ge- 
Table 1. Stage II: Selected derived values of soil strength parameters of deposits which compose the crown of the Warsaw Slope

\begin{tabular}{|c|c|c|c|c|c|c|c|c|c|c|c|c|c|}
\hline \multirow{3}{*}{$\begin{array}{l}\text { Soil type (code) by } \\
\text { PN-EN ISO } 14688\end{array}$} & \multirow{3}{*}{$\begin{array}{l}\text { Deposit origin, } \\
\text { stratigraphy (code) }\end{array}$} & \multicolumn{4}{|c|}{ Cohesion $c[\mathrm{kPa}]$} & \multicolumn{4}{|c|}{$\begin{array}{c}\text { Internal friction angle } \\
\varphi\left[^{\circ}\right]\end{array}$} & \multicolumn{4}{|c|}{$\begin{array}{l}\text { Unit weight of soil } \\
\qquad \gamma\left[\mathrm{kN} / \mathrm{m}^{3}\right]\end{array}$} \\
\hline & & \multicolumn{12}{|c|}{ Parameter sets } \\
\hline & & 1 & 2 & 3 & 4 & 1 & 2 & 3 & 4 & 1 & 2 & 3 & 4 \\
\hline $\begin{array}{l}\text { Sandy-clayey silt } \\
\text { and clayey sand } \\
\text { (saclSi/clSa) }\end{array}$ & $\begin{array}{l}\text { Glacial, Wartanian } \\
\text { Glaciation (gQp3.2) }\end{array}$ & 6.5 & 43 & 30 & 37.7 & 22 & 11.5 & 17 & 13 & 21 & 21 & 21 & 20.9 \\
\hline $\begin{array}{l}\text { Sandy-clayey silt } \\
\text { (saclSi) }\end{array}$ & $\begin{array}{l}\text { Glacial, Odranian } \\
\text { Glaciation (gQp3.1) }\end{array}$ & 3 & 49 & 45 & 54 & 32 & 15.8 & 25 & 17.4 & 22 & 21.6 & 22 & 21.1 \\
\hline
\end{tabular}

1. Results of tests in computational cross-sections (Grzelewski et al., 2009).

2. Analytical results of soils in the Mazowsze region, Poland (Pinińska, 1985).

3. Typical characteristics of soils, according to Polish standardisations (PN/B-03020, 1981).

4. Characterisation of soils used in the Engineering-Geological Atlas of Warsaw (Frankowski et al., 2000).

otechnical Polish Standards and the last on the engineering geological atlas of Warsaw (Frankowski et al., 2000).

\section{Stability evaluation procedures}

Analyses were conducted on the basis of a created relation model of destabilisation factors and used calculation techniques and slope stability prognosis. The point of reference is evaluation of slope stability conditions in their natural state, without anthropogenic factors involved. These components have an impact on slope stability state, which is described by calculation coefficient SF (Safety Factor). According to Duncan \& Wright (2005) the most widely used definition of SF for slope stability is:

$$
\mathrm{SF}=\frac{\text { shear strength of the soil }}{\text { shear stress required for equilibrium }}
$$

In order to assess the influence of computational technique on $\mathrm{SF}$, a comparison was performed of the SF results obtained by two different techniques which are in common use. Thus, the third stage of slope stability simulations (in the natural state of slopes) was conducted by two alternative methods: Bishop (by GeoStudio software) and finite elements (by Plaxis software). The theoretical basis of the numerical methods that were used to compute SF was described by Abramson et al. (2001), and for a detailed discussion reference is made to Duncan \& Wright (2005). Table 2 presents the results of SF calculations.

The similar results of SF values of calculations are a consequence of circular-cylindrical slip surface, as is typical of slopes composed of cohesive soils under natural conditions (Duncan \& Wright,
2005). The difference between SF values obtained by the Bishop method and FEM is less than $9 \%$. The Bishop method was selected as a suitable method in further studies of engineering geological conditions, especially as it is frequently used in practice.

Landslide activity can be initiated by both natural and anthropogenic causes. Natural causes include changes in soils due to weather conditions and, in part, hydrogeological effects. Anthropogenic determinants - static and dynamic loads - are related to stress changes in the soil (Pinińska et al., 1993). Calculation procedures involve simulation techniques, field observations, archive record analysis and locations of cross-sections. The following factor groups are applied:

1. Spatial factors (geometric):

- dip of the soil layer composing the slope crown,

- angle of slope, which may be subject to optimisation.

2. Ground water conditions:

- optional soil strength parameter sets (Table $1)$,

- ground water table in typical and flood conditions.

3. Types and load values:

- static loads from the burden of buildings on the crown of the slope,

- dynamic loads induced by vehicular traffic with intensity determined by reference observations performed at St. Catherine's Church in the Ursynów district (Tuchołka et al., 2008; Kaczyński et al., 2010).

The above classification enables us to create dendrograms (Figs. 5, 6), illustrating the schemes of multivariate modelling slope stability calculations at the sites studied. The large number of components affecting slope stability requires qualitative and quantitive evaluation of their role. Results of 
Table 2. Stage III: Comparison of different slope stability calculation techniques results in the reference slopes state loaded by their own weight

\begin{tabular}{|c|c|c|c|c|c|}
\hline \multirow[b]{2}{*}{$\begin{array}{l}\text { Location } \\
\text { of computational } \\
\text { cross-sections }\end{array}$} & \multirow[b]{2}{*}{ Load conditions } & \multirow[b]{2}{*}{ Parameter sets } & \multicolumn{3}{|c|}{ Calculation results of Safety Factor (SF) } \\
\hline & & & $\begin{array}{l}\text { Bishop } \\
\text { method }\end{array}$ & $\begin{array}{l}\text { Shear strength } \\
\text { reduction method }\end{array}$ & $\begin{array}{c}\text { Percentage } \\
\text { difference } \\
\text { of SF results } \\
{[\%]}\end{array}$ \\
\hline $\begin{array}{l}\text { Along the axis of } \\
\text { planned South Ring } \\
\text { Road }\end{array}$ & \multirow[t]{2}{*}{$\begin{array}{l}\text { Reference state } \\
\text { of natural own } \\
\text { soil weight }\end{array}$} & \multirow{2}{*}{$\begin{array}{l}\text { Based on results of tests } \\
\text { performed in the location of } \\
\text { computational cross-section } \\
\text { (STAGE II; parameter set } \\
\text { no. 1) }\end{array}$} & 1.342 & 1.289 & 3.9 \\
\hline Near Kiedacza Street & & & 1.398 & 1.512 & 8.2 \\
\hline
\end{tabular}

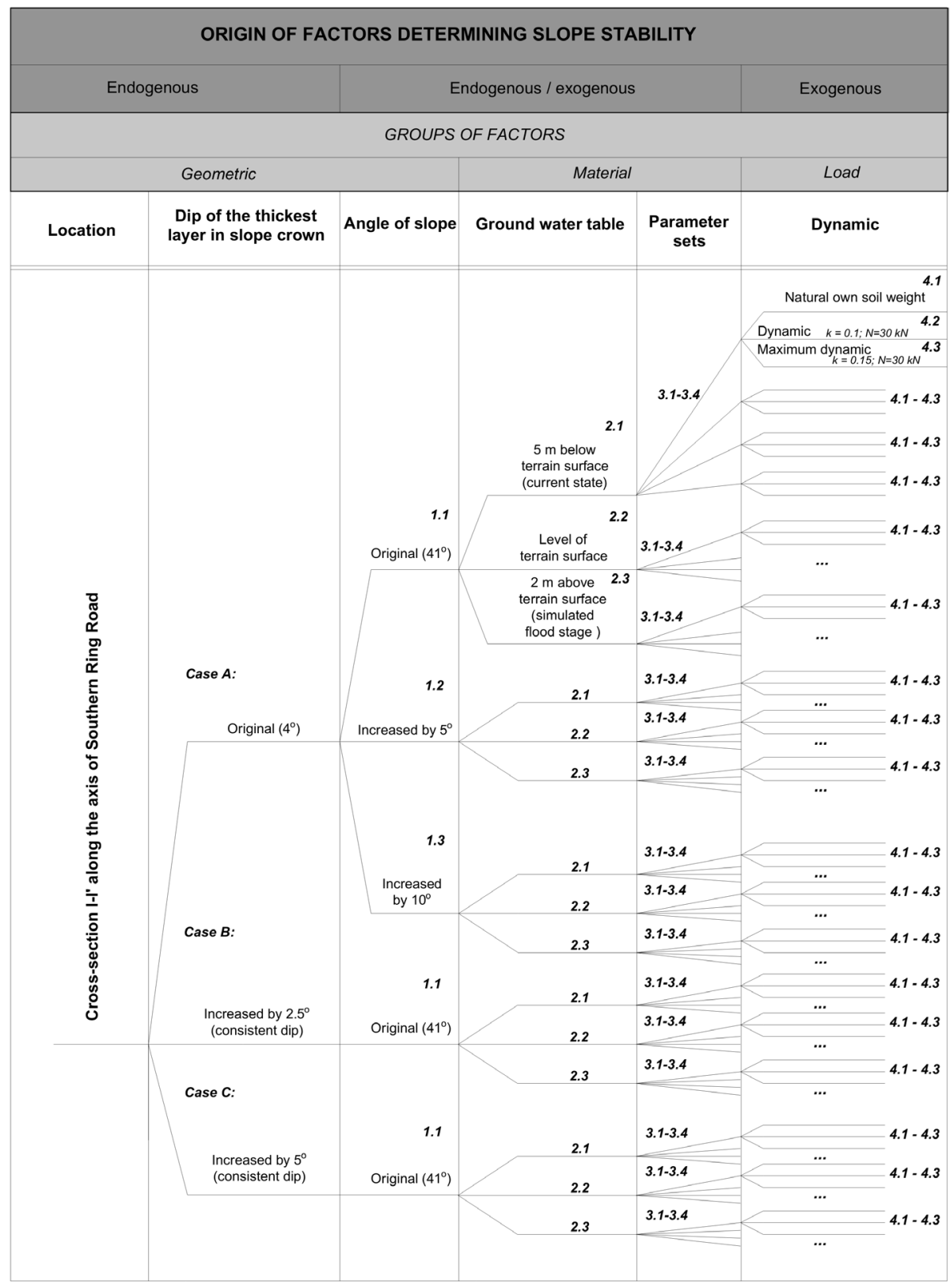

Fig. 5. Stage IV. Determination of multi-variate schemes (dendogram) of slope stability analysis with ordinal number of specific cases for cross-section along the axis of the Warsaw South Ring Road. In order to identify the destabilising factors, a code number is assigned to each of them. Therefore, singular tracks show the interaction of individual components in a particular scenario 


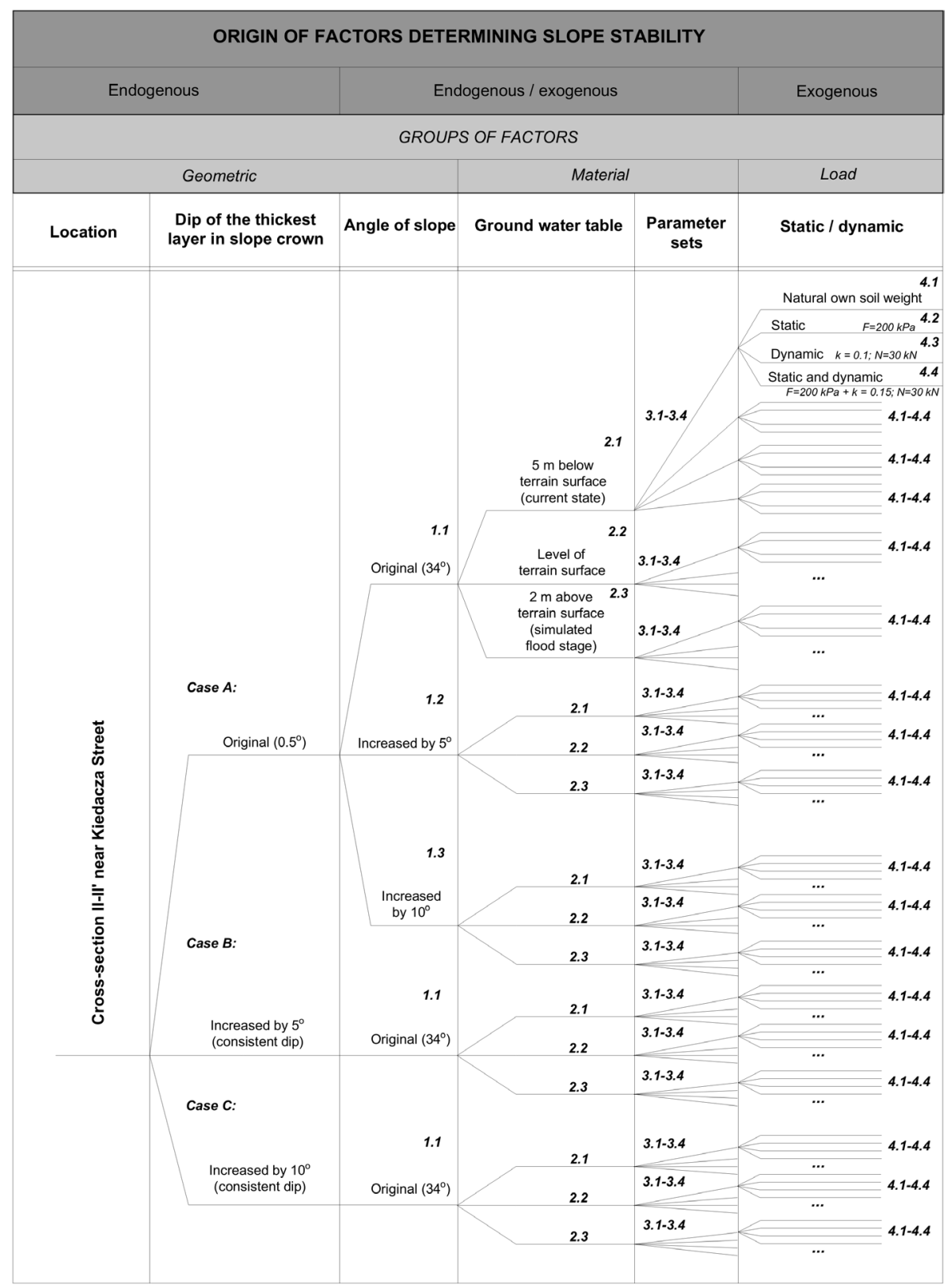

Fig. 6. Stage IV. Determination of multi-variate schemes (dendogram) of slope stability analysis with ordinal number of specific cases for cross-section near Kiedacza Street. In order to identify the destabilising factors, a code number is assigned to each of them. Therefore, singular tracks show the interaction of individual components in a particular scenario

this part of analysis led to the next scheme. In this step, the slope with natural load (generated by its own weight) was assumed as the reference state. Then five load factors were determined: three angles of slopes, three angles of thickest soil layers dip, three optional levels of one ground water table, four parameter sets of the thickest deposit layer in the slope crown and three levels of loads. The impact of each factor analysed is studied in the background of the natural state of slope (Code of case in Figs. 5, 6: case A/1.1/2.1/3.1/4.1). Thus, the high- est impact load factors were identified. Next, the cumulative influence of combined destabilisation factors was simulated, due to the high possibility of a mass movement trigger moment as a complex summary of many components.

\section{Results and discussion}

The factors affecting slope stability are physically mutually incomparable. Nevertheless, values 

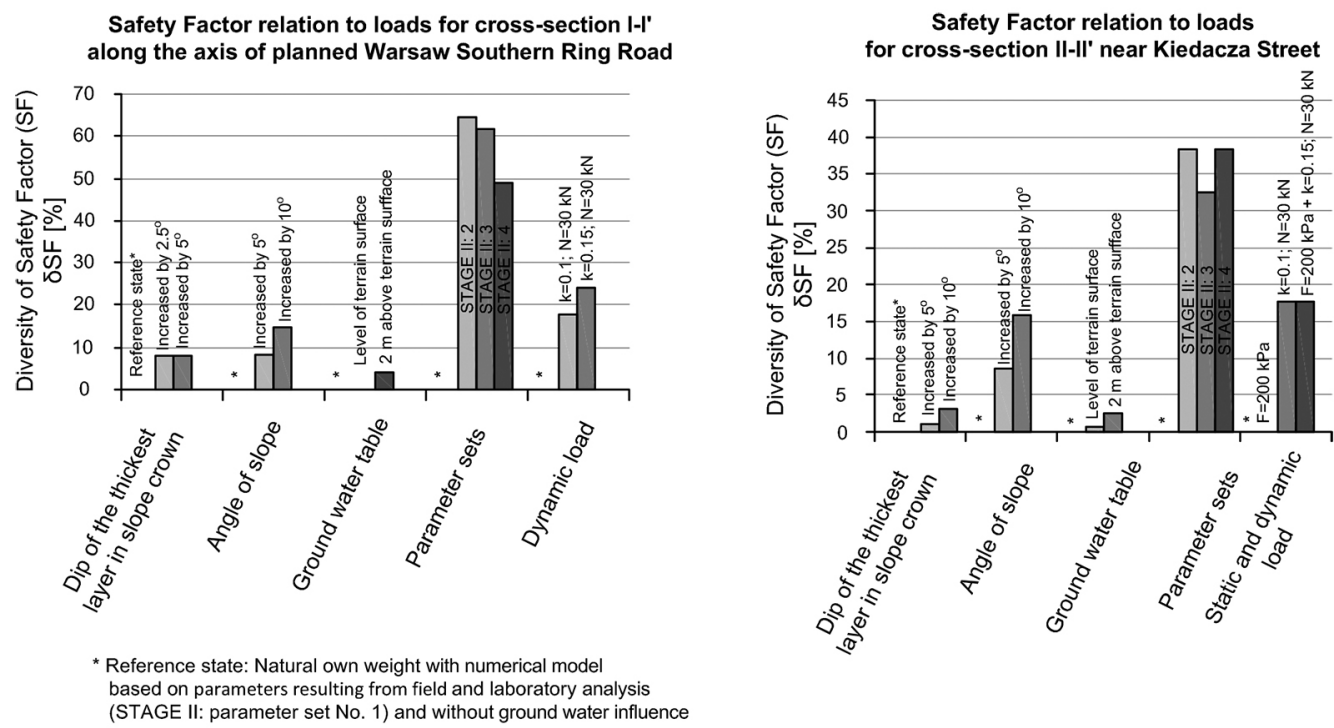

Fig. 7. Stage V. Evaluation of destabilisation load influence on slope stability

of parameters characterising the factors discussed were selected in relation to the actual and different possible changes of engineering geological situation. Therefore, it is reasonable to compare and evaluate the different impacts on slope stability, as expressed by Safety Factor reduction.

Results of the approximately 450 simulations performed during the present study allowed to present Safety Factor reduction ( $\delta S F)$ in relation to the reference state of slope, which has the most favourable natural conditions, without anthropogenic impacts (Fig. 7). Thus, the greatest factors for stability deterioration can be identified:

$$
\delta S F=\left|100\left(\frac{\Delta S F}{S F^{\text {ref }}}\right)\right|[\%]
$$

where:

SSF - Safety Factor reduction of slope [-],

$\Delta S F$ - difference between the reference state and

Safety Factor obtained after the simulated slope

loading [-], $\mathrm{SF}^{\text {ref }}$ - reference Safety Factor [-].

Based on the outcome of the calculations presented it can be concluded that changes in strength parameters and loads will have mostly an adverse impact on slope safety. All listed partial factors can be considered to be complementary.

The issue of the relationship between strength parameters and slope stability will be considered as a three-dimensional relationship $\mathrm{SF}=\mathrm{f}(\varphi, \mathrm{c})$. For the assumed loading conditions and the geometry of landslide surface, SF calculation using the Bishop method was performed with variant sets of $\varphi$ and $\mathrm{c}$ values. Approximation of the simulation re- sults presented in the 3D-system (SF, c, $\varphi$ ) provided a surface close to the plane with contour lines corresponding to different values of the Safety Factor. This allowed us to create a map that enabled a rough evaluation of soil parameters $(c, \varphi)$ influencing slope stability to be made. In many cases (including the above-mentioned tests) it is crucial to predetermine the effect of simultaneous internal angle friction reduction and cohesion growth on the slope stability state. The function $\varphi=a_{1} \cdot c+a_{2} \cdot S F+$ $\mathrm{a}_{3}$ for each determined slope, landslide line, static and/or dynamic loading assumed SF value reveal the evaluation of this relationship. Figure 8 presents the suitability of the above-mentioned 3D-approximation. On the 3D-map (SF, c, $\varphi$ ) generalised parameters of soil studies conducted at various times and with different methods were plotted. The presented 3D-relationship approximately provides an impact estimation of changes in strength test results on slope stability predictions. Additionally, Figure 8 illustrates how consistency index $\left(\mathrm{I}_{\mathrm{C}}\right)$ reduction for cohesive soils with standard characteristics affects the "reduction path" of slope Safety Factors. As mentioned earlier, the inserted 3D-relationship is an approximate solution. The coefficients of the surface equation $\varphi=a_{1} \cdot c+a_{2} \cdot S F+a_{3}$ literally depend of the angle of slope, assumed slip surface, active loads and homogeneity of strength parameters. For instance, modification of the strength parameters and/or changes in load alter the geometry of the most unfavourable slip surface and cause variations in the relationship expressed by the plane equation.

Examples of these changes are illustrated in Fig. 9, which shows a contour plane of Safety Factors, 


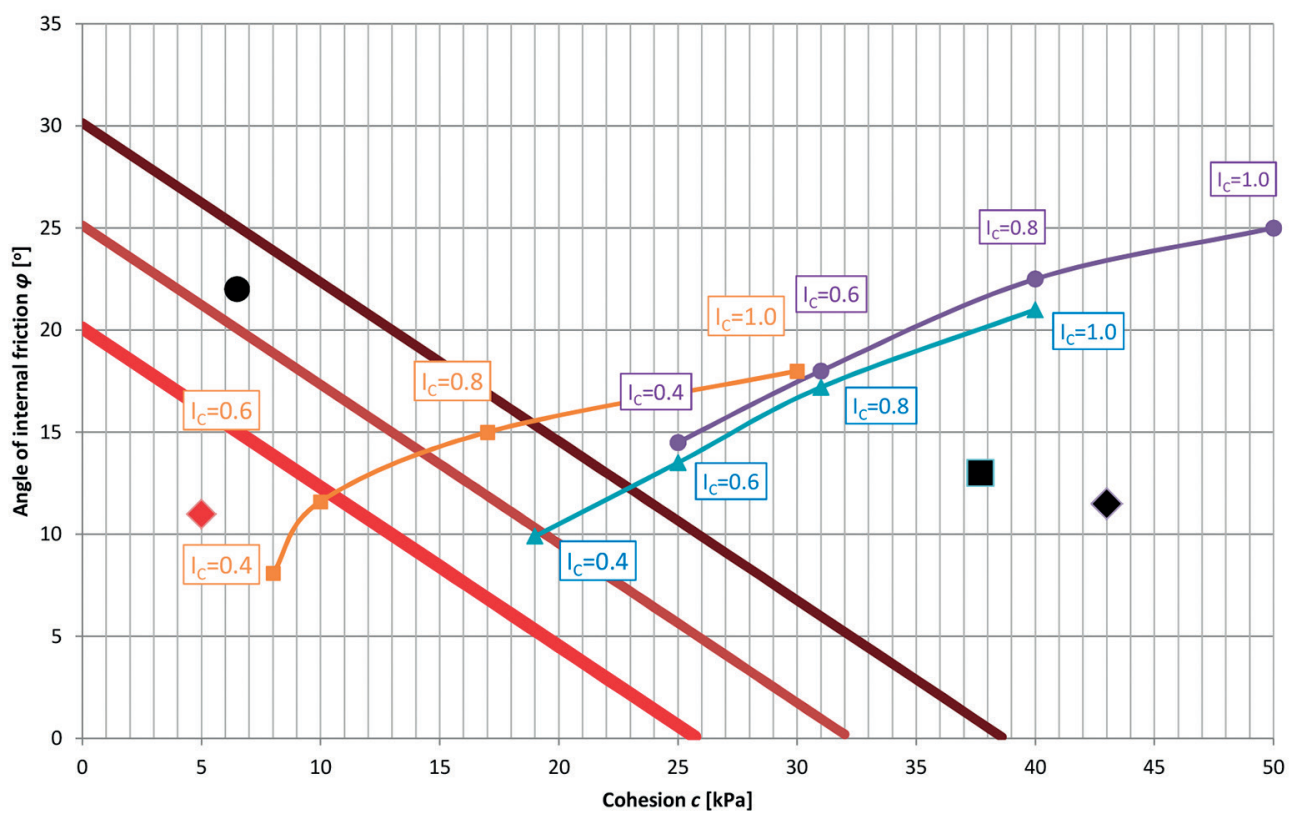

$\begin{array}{ll}\text { Characteristic line of SF=1.5 (for scenario A/1.1/2.1/3.1/4.1) } & \text { Characteristic line of SF=1.25 (for scenario A/1.1/2.1/3.1/4.1) } \\ - \text { Characteristic line of SF=1 (for scenario A/1.1/2.1/3.1/4.1) } & - \text { - Soil type: A (overconsolidated tills; PN/B-03020, 1991) } \\ - \text { Soil type: B (nonconsolidated tills; PN/B-03020, 1991) } & - \text {-Soil type: C (other cohesive soils; PN/B-03020, 1991) } \\ \text { - Parameter set No. } 1 \text { (Grzelewski et al., 2009) } & \text { - Parameter set No. } 2 \text { (Pinińska, 1985) } \\ \text { - Parameter set No. } 4 \text { (Frankowski et al., 2000) } & - \text { Fissured tills from research area (Pinińska, 1985) }\end{array}$

Fig. 8. Quantification of destabilisation factors equivalents for cross-section I-I' (Stage VII). Soil strength characteristics for selected slope stability state

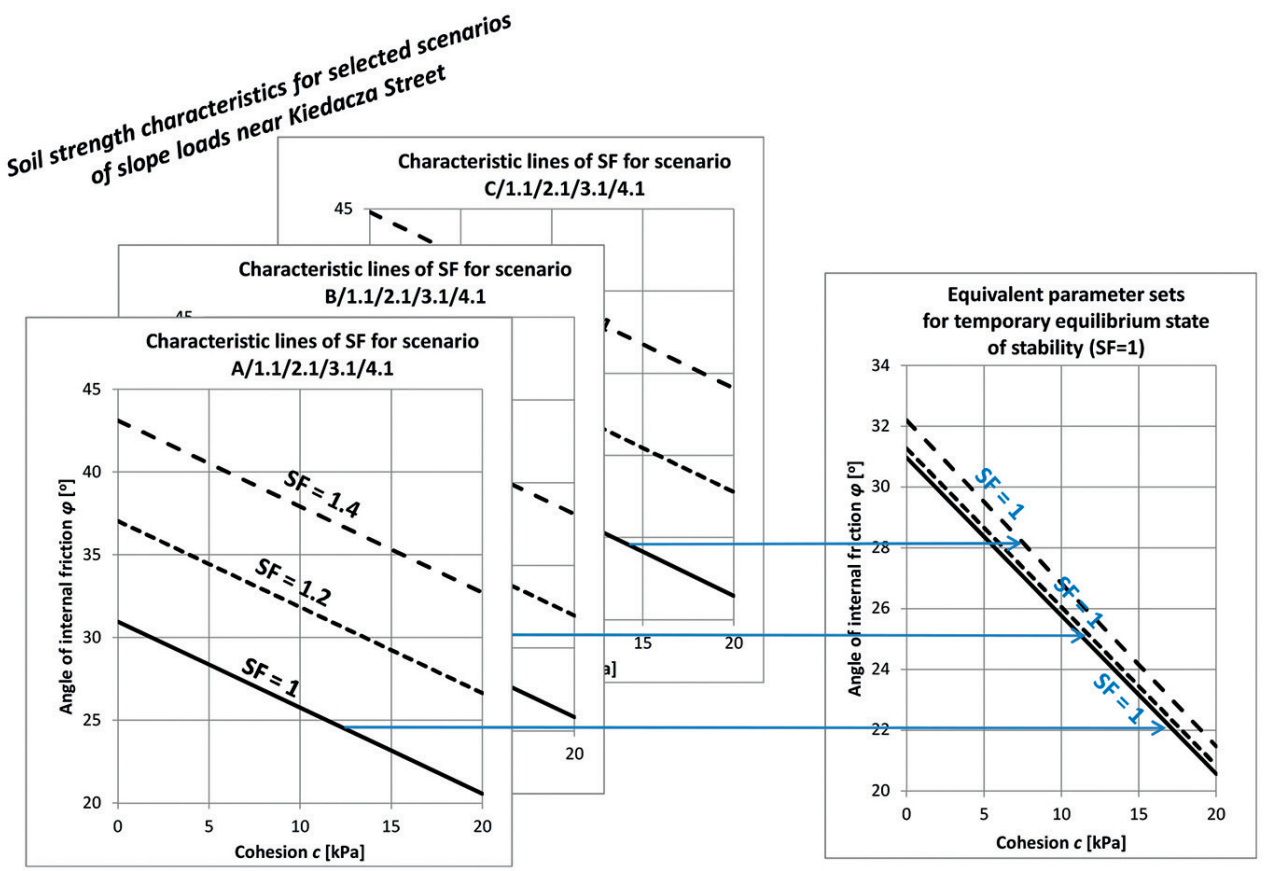

Fig. 9. Stage VII. Soil strength characteristics for selected scenarios of slope loads near Kiedacza Street (quantification of destabilisation factors equivalents). Information on code numbers of the scenario analysed from the dendrogram is in the title of each chart 
cohesion and internal friction angle at various load conditions. Lines corresponding to $\mathrm{SF}=1$ in the collective graph are shifted relative to each other, as a result of the above-mentioned changes in the loading conditions and the location of the most unfavourable slip surface. Furthermore, it should be borne in mind that the presented method basically assumes the homogeneity of strength parameters. In the case of multilayer soil systems the averaged parameters by weight method should be used. Nevertheless, the presented visualisation can be a useful tool for approximate assessment of the impact of changes in strength parameters (e.g., due to moisture and structure changes) on slope stability.

Landslide creation or activation is treated as a phenomenon caused by the superimposition of several factors or as an event caused primarily by one - often extraordinary - impulse. Argumentation of the simultaneous impact of several factors generally requires advanced modelling and the results are always optional. This entails the question of quantitative determination of equivalent influence of different factors. The model calculations illustrate the diverse impacts of factors on changes in slope safety. For example, in one of the cases analysed the Safety Factor reduction in the range of 1.29 to 1.16 can be caused by a dynamic load with seismic coefficient reduction $\Delta \mathrm{k}=0.06$ or an angle of slope reduction $\Delta \mathrm{a}=6.8$ (Fig. 10).

Quantitative tools for comparison are:

- approximation linear slope of SF relation with the analysed factor affecting variability,

- correlation coefficient of the concerned relationship.

Figure 10 presents the effect of model calculations, which shows that in the studied engineering geological conditions the factors with the least impact on SF change were: the spatial position of the thickest layer in the crown of the slope and the optional position of the groundwater table. The significance of these factors was negligible because of the geological structure and the limited fluctuations in ground water table at the foot of the slope. In contrast, the angle of the slope and the dynamic loads impact greatly on slope stability. Either the first or the second of these factors depend of the designed geotechnical solutions. Thus, it is possible in the course of the study and modelling to determine

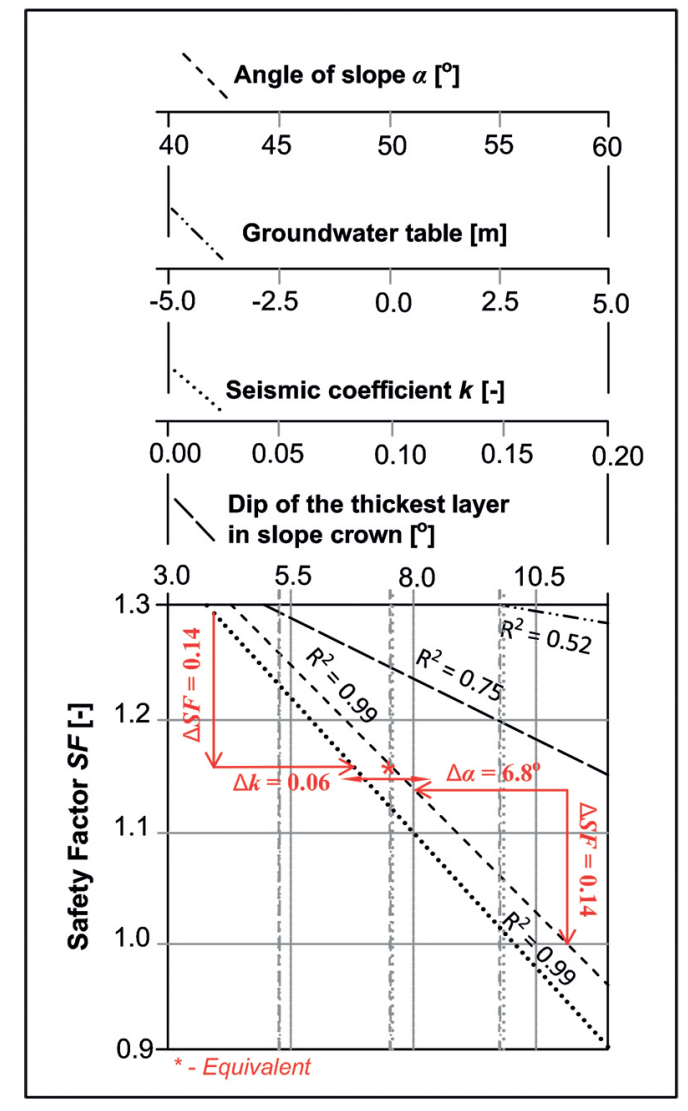

Fig. 10. Implementation Stage VII. Quantification Application of various slope load scheme calculation results (Stages IV and V) to quantitative assessment of equivalence factors aggravating the slope in the axis of planned Warsaw Southern Ring Road 
optimal and safe conditions for the stability of the slope.

\section{Conclusions}

In the area analysed along the plateau slope, where the Warsaw South Ring Road is planned, landslide activity has been observed. Local landslide was activated in 2010 near the sections analysed. The results of numerous and various numerical simulations of mass movement activity also show SF values close to 1 . It is an important warning signal for the Southern Ring Road which is to cross the Warsaw Slope.

Results of SF obtained by the Bishop method and FEM were similar in the analysed landslides simulations for natural state of slope. Therefore, the former was chosen as faster and less complicated to following studies of engineering geological conditions.

The design of safe slope geometry in the analysed transition area of plateau and Vistula Valley requires consideration of natural and anthropogenic stability components such as:

- changes in soil properties due to meteorological and hydrological factors,

- relationship between the dip of soil layers and slope inclination,

- expected static and dynamic loads.

In the present paper six steps of slope stability analysis were indicated for optimum design of slopes in relation to the proposed development. Analysis of slope stability conditions, including a division between natural and anthropogenic factors, allows us to create a modelling dendrogram for the purposes of engineering geological evaluation and design management of slopes.

The computational simulations showed that in the analysed engineering geological conditions the greatest threat to slope stability is through a reduction in shear strength due to periodic yielding of soil in the slip surface and dynamic load areas. Each of these factors independently may lead to the activation of surface mass movements and their superimposition indicates a high risk of landslide.

Three-dimensional three surfaces (SF, c, $\varphi$ ) are a useful tool for analysing slope stability conditions, as they can be used to provide an approximate evaluation of the impact of changes in strength parameters. Based on model calculations, it is possible to evaluate equivalent changes in destabilisation factors leading to a comparable reduction in slope safety conditions.
The realised evaluation of Warsaw Slope stability conditions shows that the proposed methodology of analysed cases is convenient for practical use. This procedure includes:

- multi-stage approach of performed analysis,

- comparison of results of alternative calculation methods (classic Bishop method and FEM),

- analysis of 3D-maps (SF, $\varphi, c)$,

- quantitative analysis of geometrical, geotechnical and load factors.

The methodology of slope stability analysis presented can be applied to different variants of slope-forming tests with various scenarios dedicated to specific engineering geological conditions, with fast evaluation of changes in stability.

\section{References}

Abramson, L.W., Lee, T.S., Sharma, S. \& Boyce, G.M., 2001. Slope Stability and Stabilisation Methods, $2^{\text {nd }}$ edition, John Wiley \& Sons, 736 pp.

Dobak, P. \& Pinińska, J., 1987. Zmienność parametrów geotechnicznych w wrunkach budowy metra w Warszawie [Variability of geotechnical parameters in the course of construction of the Warsaw underground]. Przeglad Geologiczny 2, 73-79 (in Polish with English summary).

Duncan, J. M. \& Wright, S. G., 2005. Soil strength and slope stability. John Wiley \& Sons, 312 pp.

Frankowski, Z., Bażyński, J., Lewkowicz, M., Wysokiński, L., Majer, E. \& Łukasik, S., 2000. Atlas geologiczno-inżynierski Warszawy w skali 1 : 10000 [Geological-engineering atlas of Warsaw, scale 1:10,000]. Polish Geological Institute, Warszawa. 83 pp. (in Polish).

Grzelewski, E., Pabich, M. \& Socha, T., 2009. Dokumentacja geologiczno-inżynierska dla ustalenia geotechnicznych warunków posadowienia tunelu pod dzielnica Ursynów, na trasie projektowanej Potudniowej Obwodnicy Warszawy, na odcinku od węzła "Puławska" do węzła "Lubelska" [Engineering geological report for the tunel under Ursynów area, Warsaw Southern Ring Road]. Arcadis, Warszawa, 53 pp. (in Polish).

Kaczmarek, Ł., 2014. Geomorphological and geophysical analysis of the Warsaw slope stability conditions in the Ursynów district. Scientific Review. Engineering and Environmental Sciences 23, 215-226.

Kaczyński, R., Bąkowska, A. \& Kiełbasiński, K., 2010. Zachowanie się glin lodowcowych z warszawskiego Ursynowa podczas obciążeń statycznych i dynamicznych. [Stress-strain behaviour of glacial till from the Ursynów suburb of Warsaw under static and dynamic loading]. Przeglad Geologiczny 58, 873-878 (in Polish with English summary).

Kaczyński, R., 2011. Engineering-geological characteristics of typical soils in Poland. Biuletyn Państwowego Instytutu Geologicznego 446, 329-340 (in Polish with English summary). 
Koda, E. \& Rabarijoely, S., 2013. Numeryczna ocena stateczności i warunków posadowienia kościoła na krawędzi Skarpy Warszawskiej [Numerical assessment of stability and foundation conditions of a church located on the edge of "skarpa warszawska"]. Budownictwo i Inżynieria 4, 27-35 (in Polish with English summary).

Tucholka, P., Kiełbasiński, K. \& Mieszkowski, R., 2008. Tracing seismic surface waves induced by road traffic in Urban environment: example of St.Catherine's Chuch Hill in Warsaw. Geologija 50, S79-S84.
Pinińska, J., Dobak, P. \& Łukaszewski, P., 1993. Ocena stateczności zboczy drogi międzyregionalnej w warunkach fliszu karpackiego [Slope stability evaluation of interregional road in the conditions of Carpathian flysch]. Konferencja Mechanika Gruntów i Fundamentowanie, Warszawa, 299-306 (in Polish).

Wysokiński, L., 1999. Warszawska skarpa śródmiejska [Vistula Valley Slope in Warsaw downtown]. Drukarnia Piotra Włodarskiego, Warszawa, 145 pp. (in Polish).

Manuscript received: 22 July 2015 Revision accepted: 2 November 2015 